Received: July 19, 2015

\title{
School Administrators' Opinions on Frequently Changing Regulations Related to Appointments and Relocation: A New Model Proposal ${ }^{*}$
}

\author{
Şenol Sezer ${ }^{1}$ \\ Ordu University
}

\begin{abstract}
The purpose of this study is to reveal school administrators' opinions on frequently changing regulations related to appointments and relocation and to offer a new model. A qualitative research design was employed. The study participants were 20 school principals and 20 vice principals working in the Ordu, Giresun and Trabzon city centres during the 2014-2015 academic year. They were selected through a criterion sampling method. Semi-structured interviews were used as the data collection tool. One main theme with six sub-themes was determined to identify the positive aspects of frequently changing regulations, and 13 sub-themes were used to identify the negative aspects. The main theme of the positive aspects was motivation and clarity. The main themes for the negative aspects were (i) favouritism and (ii) administrative problems. Seventeen criteria were determined with regard to school administrators' appointment and relocation. The main themes for these criteria were (i) administrative skills, (ii) training and experience and (iii) scoring. The findings showed that the school administrators' opinions are generally negative related to frequently changing regulations. The findings revealed that the frequently changing regulations cause favouritism and administrative problems in the appointment process for school administrators. A new model is also offered in this study.
\end{abstract}

Keywords

School management $\bullet$ Principal $\bullet$ Regulation $\bullet$ Appointment $・$ Relocation $\bullet$ Model proposal

* This study is an extended form of the paper presented at the 10th National Educational Administration Congress held in Gaziantep University on May 7-9, 2015

1 Correspondence to: Şenol Sezer (PhD), Department of Education Science, Ordu University, Ordu Turkey. Email: senolsezer.28@gmail.com

Citation: Sezer, S. (2016). School administrators' opinions on frequently changing regulations related to appointments and relocation: A new model proposal. Educational Sciences: Theory \& Practice, 16, 335-356. 
Recruitment, selection, training and retention of school administrators have great importance for all education systems because effective educational leadership is vital to provide improvement in all educational activities and processes for schools that foster student learning. Appointments based on traditional in-service training fail to meet the learning needs of increasingly diverse student bodies. In recent years, there has been a growing consensus that school administrators should be selected and trained in leadership programmes and theory and practice should be combined in the training process.

Typically, each school has a principal who is responsible for the school's operation (Degenhardt, 2006; Lashway, 2003; Portin, Alejano, Knapp, \& Marzolf, 2006; Salazar, 2007). In many countries, the school principal is an elected administrator (Lunenburg, 2010). School principals are generally decided by an official representative, multimember committee or school board (Bolivar \& Moreno, 2006). The most frequently used selection criteria are management and/or leadership experience (in Austria, Denmark, Ireland, Israel, Northern Ireland, Portugal and Spain), additional academic or other qualifications (in Austria, Ireland, Northern Ireland, Portugal and Spain), interpersonal and personal skills (in Austria, Denmark, Ireland and Northern Ireland), vision/values for school leadership (in Austria, Denmark, Ireland and Israel) and quality of work proposals for the school (in Austria, Denmark, Ireland and Israel) (Pont, Nusche, \& Moorman, 2008).

In Turkey, it cannot be said that an effective and sustainable project related to school principals' training and appointment is available yet. In addition, many studies related to in-service training and the appointment processes for school administrators have been conducted. While some of these studies suggest a new model, e.g. Altın and Vatanartıran (2014), Balyer and Gündüz (2011), Cemaloğlu (2005), Çelenk (2003), Ereş (2009) and Iş1k (2003), some of them analyse the current situation and offer solutions to problems, e.g. Akçadağ (2014), Demirtaş and Özer (2014), Helvacı and Aydoğan (2011), Karip and Köksal (1999), Korkmaz (2005), Okçu (2011), Özmen and Kömürlü (2010) and Turan, Yıldırım, and Aydoğdu (2012). According to Işı1k (2003), although there are some important developments in the selection and employment of school principals and some developments encouraging the establishment of such programmes in the Turkish Educational System, the Ministry of National Education never requires a certificate for school principal appointment.

An appointment and relocation regulation published in the Official Gazette in September 1998 had brought a two-phased examination system for candidates seeking to be school administrators. According to the regulation, candidates who pass the first exam need to complete a 120 -hour in-service training programme, and they can obtain a management certificate if they score at least 70 points out of 100 on the post-training evaluation exam. This ended the master-apprentice system that had long been used for 
school administrators' training. According to Taş and Önder (2012), the 1998 regulation can be regarded as the beginning of professionalism in educational management.

In the process starting with the regulation published in the Official Gazette on April 1999, school administrators' selection and appointment were performed in a framework of a series of instructions that changed frequently (Şişman \& Turan, 2004). Within the last 25 years, the Ministry of Education has made many changes to regulations related to the appointment and relocation of school managers. From 2004 till 2010, approximately 30 regulations or public mandates were implemented to solve problems related to appointment and relocation. The appointments based on regulations frequently changed by the Ministry have not satisfied school administrators and have led to court cases (Taş \& Önder, 2012). Furthermore, school administrators have called for abolishing the regulations and cancelling the appointments. The cases were concluded on behalf of school administrators by the State Council, and consequently, school administrators were not appointed permanently in 2004-2010. Moreover, this caused many schools and institutions to be managed vicariously. Because of the cancellation of the regulations, in 2008-2009, the Ministry made direct appointments using its authority given by the $71^{\text {th }}$ and $76^{\text {th }}$ articles of the Civil Servants Law No. 657 (Resmi Gazete, 1965). However, a number of actions for nullity were sued to the Administrative Courts, and many appointments were annulled by the Administrative Courts (Aslanargun, 2012). According to one of the latest regulations dated June 2014, school principals are to be appointed on the basis of professional seniority, managerial experience, oral exam (interviews) points and evaluation scores. Evaluation scores are given by senior managers (district national education director, branch manager or branch manager in-charge of human resources), teachers (with the most and least seniority), two teachers selected by the teachers board, student council president and Parent-Teacher Association president and vice president (Resmi Gazete, 2014).

The Unions have asked the State Council to annul some of the articles in a regulation dated June 2014. In addition, the underserved or relocated school principals according to new regulations have asked the Administrative Court to supersede appointments, and a number of the cases have resulted in their favour. Frequently changing regulations with slight differences are perceived as a way to depose existing principals and appoint new principals who are affiliated with the ruling party. Moreover, instability reduces school effectiveness and disrupts labour peace. Therefore, in line with the proposals and opinions of all stakeholders, the development and implementation of a new, permanent and sustainable model for choosing, training and appointing school administrators is a priority case now more than ever for the Turkish Education System. This study aims to reveal school administrators' views on frequently changing regulations and to offer a new training and appointment model. 


\section{Method}

\section{Design}

This study was designed to fill in the knowledge gaps concerning the selection, training and appointment of school administrators. For this purpose, the aim was to reveal school administrators' opinions related to frequently changing regulations and to offer a new model. A qualitative research method was adopted. The qualitative research method is used to obtain in-depth information about a topic (Denzin \& Lincoln, 2005; Marshall \& Rossman, 2006; Singh, 2007). This study used a case study pattern, which is one of the qualitative research methods (Creswell, 2015, p. 96).

\section{Participants}

The participants were 20 principals and 20 vice principals working in the Ordu, Giresun and Trabzon city centres during the academic year 2014-2015. They were selected through the criterion sampling method. Being relocated was considered as the prerequisite criterion. This criterion has also been taken as a baseline because relocated school administrators are aware of the regulations on the appointment and relocation of school administrators. Professional seniority was considered as another criterion. In addition, school administrators' managerial seniority was considered as another criterion. Regulations are evaluated by school administrators in different ways because both administrators' professional seniority and managerial seniority influence their opinion. The study was conducted with school administrators who serve in different cities to reach more relative results considering applications in different cities. In addition, membership in different unions was selected as a criterion to ensure the representation of school administrators' different views as objectively as possible. The demographic characteristics of the participants are given in Table 1.

\begin{tabular}{|c|c|c|c|c|c|c|c|c|c|}
\hline \multicolumn{10}{|c|}{$\begin{array}{l}\text { Table } 1 \\
\text { Demographic Characteristics of the Participants }(\eta=40)\end{array}$} \\
\hline Duty Place & $\eta$ & Position & $\eta$ & $\begin{array}{l}\text { Professional } \\
\text { Seniority }\end{array}$ & $\eta$ & $\begin{array}{l}\text { Managerial } \\
\text { Seniority }\end{array}$ & $\eta$ & Union & $\eta$ \\
\hline Ordu & 14 & Principal & 20 & 1-6 Years & - & 1-6 Years & 14 & Eğit. Bir-Sen ${ }^{1}$ & 21 \\
\hline Giresun & 13 & Vice principal & 20 & $7-12$ Years & 3 & 7-12 Years & 13 & Türk Eğit. Sen² & 7 \\
\hline \multirow{4}{*}{ Trabzon } & 13 & & & 13-18 Years & 16 & 13-18 Years & 6 & Eğitim-Sen ${ }^{3}$ & 3 \\
\hline & & & & 19-25 Years & 8 & 19-25 Years & 3 & Eğitim-İş ${ }^{4}$ & 1 \\
\hline & & & & Over 25 Years & 13 & Over 25 Years & 4 & Aktif Eğit. Sen ${ }^{5}$ & 1 \\
\hline & & & & & & & & Non-member & 7 \\
\hline Total & 40 & & 40 & & 40 & & 40 & & 40 \\
\hline
\end{tabular}

(1) Eğitim Bir-Sen (Union of Educators): This union ranks first in terms of the number of members (Resmî Gazete, 2015). 
(2) Türk Eğitim-Sen (Education Workers' Union of Turkey): This union ranks second in terms of the number of members.

(3) Eğitim-Sen (Education and Science Proletarians' Union): This union ranks third in terms of the number of members.

(4) Eğitim İş (Union of Employees in Education and Science): This union ranks fourth in terms of the number of members.

(5) Aktif Eğitim-Sen (Active Educators Union): This union ranks fifth in terms of the number of members.

\section{Procedure}

The study was conducted in four stages: (i) definition of the problem, (ii) preparation of the data collection instrument, (iii) data collection and (iv) data analysis and interpretation (Karadağ, 2011).

Definition of the problem. During interviews with school administrators, it is understood that frequently changing regulations related to school administrators' appointment and relocation causes various problems. Moreover, the regulations reduce the principals' morale and motivation. Therefore, it is necessary to determine the defective aspects of the existing procedures and to identify an ideal model for school administrators' employment.

Preparation of the data collection instrument. A semi-structured interview form was used for data collection. The form was prepared in two stages. First, questions about the participants' demographic characteristics were developed. Then, openended questions were written on the basis of an expert's opinions. The semi-structured interview form consisted of two parts. The first part contained five questions about the participants' demographic characteristics and the second part contained the following three open-ended questions: (i) What are the positive aspects of frequently changing regulations? (ii) What are the negative aspects of frequently changing regulations? (iii) Which criteria should be considered in the appointment and relocation process used for school administrators?

Data collection. The research called each principal and vice principal to schedule an appointment and then gave out the semi-structured interview form. The interviews lasted for about 20 minutes, and the school administrators expressed their views in writing in response to the open-ended questions.

Data analysis. The data were transferred to a computer via Microsoft Excel and analysed using descriptive analysis. This method consists of four stages: creating a thematic framework for analysis, processing data, identifying findings and analysis 
and interpretation (Y1ldırım \& Şimşek, 2013, p. 256). School administrators' similar responses to the same question were evaluated in the category. The written data were coded, and six sub-themes were determined to identify the positive aspects of frequently changing regulations. A single main theme was determined to identify these sub-themes: motivation and clarity. Thirteen sub-themes were determined to identify the negative aspects of regulations. Two main themes were determined to identify these sub-themes. The main themes were (i) favouritism and (ii) administrative problems. Seventeen criteria were determined to be related to school administrators' appointment, and three main themes were determined to identify these criteria. The main themes were (i) administrative skills, (ii) training and experience and (iii) scoring. The views on the sub-themes were sorted according to their frequency.

\section{Validity and Reliability}

Related literature was reviewed in-depth, and a conceptual framework was created on the subject to improve the internal validity of the study. The data were coded by the researcher and another scholar who is experienced in qualitative research. In the first stage, the themes were kept large enough to cover the concepts but narrow enough to exclude unrelated concepts. The formula "Reliability = Consensus/Consensus + Dissidence $\times 100$ " was applied to determine the reliability of the coding (Miles \& Huberman, 1994). The agreement between the two coders was calculated as $32 /(32+$ $4) \times 100=.89$. In the second phase, structural integrity was achieved by controlling the relationship between the main themes and sub-themes as well as the relationship between each sub-theme and the others. The research process was explained in detail, and all evidence was shown without comment to improve the external validity.

\section{Findings}

\section{Positive Aspects of the Frequently Changing Regulations}

In this section, the positive aspects of the frequently changing regulations are evaluated under the single theme "motivation and clarity." The terms school principal and vice principal are abbreviated as "SP" and "VP," respectively. It is impossible to state all the participants' opinions because of the limitations of space. As such, the more remarkable views have been included. These views are as follows:

[SP1] It is positive because the task period of a school principal at the same school is limited to four years.

[SP8] It can encourage success by determining the conditions of being assigned duty for more than four years at the same school. So it does not give opportunity to school principals to be in languor. 
[VP14] I find it positive because the last regulations ensure replacing or putting out to pasture the administrators who have lost their ambition to work. Every new regulation brings new criteria, and this allows willing ones to be employed as school administrators.

[VP18] I find it positive because new regulations enable young and more ambitious administrators to be appointed instead of the administrators who are aged and have no particular purpose in the profession.

The frequency and percentages of sub-themes related to the main theme of motivation and clarity are presented in Table 2.

\begin{tabular}{|c|c|c|c|c|}
\hline \multicolumn{5}{|l|}{$\begin{array}{l}\text { Table } 2 \\
\text { Sub-themes of Motivation and Clarity }(\eta=40)\end{array}$} \\
\hline \multirow{2}{*}{ Sub-theme } & Principals & Vice principals & & \\
\hline & $f$ & $f$ & Total & $\%$ \\
\hline Ineligible principal's deposal & 5 & 8 & 13 & 31.0 \\
\hline Willing principal's appointment & - & 9 & 9 & 21.4 \\
\hline Encouraging success in school administration & 5 & 4 & 9 & 21.4 \\
\hline Clarity of the task period at the same school & 6 & - & 6 & 14.3 \\
\hline Definition of certain rules for appointment & 4 & - & 4 & 9.5 \\
\hline Job enthusiasm & - & 1 & 1 & 2.4 \\
\hline Total & 20 & 22 & 42 & 100 \\
\hline
\end{tabular}

According to Table 2, the positive aspects of the frequently changing regulations are the ineligible principal's deposal ( $\mathrm{f}=13,31 \%$ ), the willing principal's appointment ( $f=9,21.4 \%$ ), encouraging success in school administration ( $f=9,21.4 \%$ ), clarity of the task period at the same school ( $\mathrm{f}=6,14.3 \%$ ), definition of certain rules for appointment $(\mathrm{f}=4,9.5 \%)$ and job enthusiasm $(\mathrm{f}=1,2.4 \%)$.

\section{Negative Aspects of the Frequently Changing Regulations}

In this section, the negative aspects of frequently changing regulations are evaluated under two main themes: favouritism and administrative problems. The views related to favouritism are as follows:

[SP3] Individuals' merits were not in the foreground. Moreover, administrative background was not considered. It can be said that favouritism was primarily applied.

[SP4] It left school administrators to the determination by local politicians, senior administrators and those who evaluated them with the score.

[SP6] The scoring system during the interviews was not fair. Moreover, the interviews were open to interference. 
[VP1] The school administrators were appointed largely with political concerns. Those who wanted to be appointed as school administrators were forced to get ratification from local politicians and to join the union, which is affiliated with the ruling party.

[VP10] The credibility of the appointments is open to discussion, and the impartiality of the school administrators who were appointed in this way is questioned due to the allegations of favouritism and influence.

[VP11] Evaluation Commission Members have exhibited particular attitudes to the candidate administrators during the interviews. It is apparent that the commission members are already informed of who will be successful in the interviews. Consequently, the principle of impartiality has been violated.

The frequency and percentages of sub-themes related to the main theme of favouritism are presented in Table 3.

\begin{tabular}{|c|c|c|c|c|}
\hline \multicolumn{5}{|l|}{$\begin{array}{l}\text { Table } 3 \\
\text { Sub-themes of Favouritism }(\eta=40)\end{array}$} \\
\hline \multirow[t]{2}{*}{ 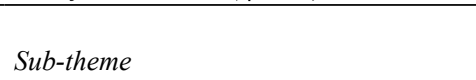 } & Principals & Vice principals & & \\
\hline & $f$ & $f$ & Total & $\%$ \\
\hline Violation of impartiality & 8 & 9 & 17 & 32.7 \\
\hline Appointment based on political concerns & 8 & 4 & 12 & 23.1 \\
\hline Favouritism in interviews & 6 & 1 & 7 & 13.5 \\
\hline Ignoring individuals' merits & 5 & 1 & 6 & 11.5 \\
\hline Influence on commission members & 3 & 2 & 5 & 9.6 \\
\hline Commission members' partial attitude & 2 & 1 & 3 & 5.8 \\
\hline Openness of interviews to interference & 1 & 1 & 2 & 3.8 \\
\hline Total & 33 & 19 & 52 & 100 \\
\hline
\end{tabular}

When Table 3 is considered, it is seen that the violation of impartiality ( $\mathrm{f}=17,32.7 \%$ ) ranks first among school principals' and vice principals' negative opinions. Appointment by considering political concerns $(f=12,23.1 \%)$, favouritism during interviews $(f=7$, $13.5 \%)$, ignoring individuals' merits $(f=6,11.5 \%)$, influence on commission members ( $f=5,9.6 \%$ ), exhibition of commission members a partial attitude ( $f=3,5.8 \%$ ) and openness of interviews to interfere $(f=2,3.8 \%)$ are mentioned by the participants as negative aspects. The views related to administrative problems are as follows:

[SP10] Due to frequently changing regulations, school administrators' motivation reduces and the productivity decreases.

[SP19] I think frequently changing regulations doesn't have any positive aspects... It caused confusion in school management.

[SP7] Administrative positions require stability and a pretty good task period. The relocation every four years causes the task period to end before the school administrators see the results of the projects they have planned. 
[SP9] School administrators are forced to be in affiliation with the ruling party to maintain their administrative positions.

[VP18] The administrative position is not considered as a tenured or staff position. Due to job insecurity, school administrators feel compelled to act in favour of the ruling party.

[VP20] Changing a school administrator's duty place has caused adaptation problems and disruption in the labour peace.

[VP2] School administrators' motivation has been completely reduced due to the frequently changing regulations. In the process of adapting to a new school, the newly appointed school administrators are confronted with difficulties. The lack of objective criteria for appointment also brings along new problems.

[VP9] I think there are no positive aspects of frequently changing regulations.

The frequency and percentages of sub-themes related to the administrative problems main-theme are presented in Table 4.

\begin{tabular}{llcccc}
\hline Table 4 & & & & \\
Sub-themes of Administrative Problems $(\eta=40)$ & & & & \\
& Sub-theme & Principals & Vice principals & \\
\cline { 2 - 5 } & & $f$ & $f$ & Total & $\%$ \\
\hline & Confusion in school management & 10 & 7 & 17 & 34.0 \\
& Lack of motivation & 4 & 6 & 10 & 20.0 \\
& Adaptation problems in new duty place & 3 & 6 & 9 & 18.0 \\
& Decrease in administrative autonomy & 5 & 2 & 7 & 14.0 \\
& Impossibility of long-term projects & 4 & - & 4 & 8.0 \\
& Decrease in productivity & - & 3 & 3 & 6.0 \\
\hline Total & & 26 & 24 & 50 & 100 \\
\hline
\end{tabular}

In Table 4, it is seen that ever-changing regulations cause administrative problems. The major administrative problems are the confusion in school management $(f=17$, $34 \%$ ), lack of motivation ( $\mathrm{f}=10,20 \%$ ), adaptation problems in new duty place $(\mathrm{f}=9$, $18 \%$ ), decrease in administrative autonomy ( $\mathrm{f}=7,14 \%$ ), impossibility of long-term projects $(f=4,8 \%)$ and the decrease in productivity $(f=3,6 \%)$.

\section{Appointment Criteria for School Administrators}

In this section, the appointment criteria of school administrators are evaluated under three main themes. The views related to administrative skills are as follows:

[SP14] School principals should be appointed considering leadership features. Besides, fairness and impartiality should be considered in appointment process. 
[SP18] The candidate who wishes to be appointed as a school principal should have leadership features, communication skills and teamwork skills.

[SP2] Ones who are willing to be appointed as a school principal should have high-level human relation skills. The candidates also should be open to personal improvement and innovations.

[VP12] A school principal should have leadership features as well as human relation skills. Above all, the principal should be consistent.

[VP20] A principal should have human relation skills, leadership features and communication skills. A school principal also should be fair and trusty.

The frequency and percentages of sub-themes related to administrative skills are presented in Table 5.

Table 5

Sub-themes of Administrative Skills $(\eta=40)$

\begin{tabular}{llcccc}
\hline & Principals & Vice principals & & \\
\cline { 2 - 5 } Sub-theme & $f$ & $f$ & Total & $\%$ \\
\hline Leadership features & 7 & 15 & 22 & 47.8 \\
Communication skills & 6 & 4 & 10 & 21.7 \\
Human relations & 1 & 4 & 5 & 10.9 \\
Fairness & 2 & 2 & 4 & 8.7 & 4.4 \\
Innovativeness & 2 & - & 2 & 4.4 \\
& Predisposition to teamwork & 2 & - & 2 & 2.1 \\
\hline Personal improvement & 1 & - & 46 & 100 \\
\hline
\end{tabular}

When Table 5 is considered, it is seen that the school administrators believe that administrative skills are of great importance in the appointment of school administrators. Leadership features take an important place among the administrative skills ( $\mathrm{f}=22$, 47.8\%). The other administrative abilities are communication skills ( $\mathrm{f}=10,21.7 \%$ ), human relations ( $\mathrm{f}=5,10.9 \%$ ), fairness $(\mathrm{f}=4,8.7 \%)$, innovativeness ( $\mathrm{f}=2,4.4 \%)$, predisposition to teamwork $(\mathrm{f}=2,4.4 \%)$ and personal improvement $(\mathrm{f}=1,2.1 \%)$.

The views concerning the main theme of training and experience are as follows:

[SP9] School principals should be appointed considering individuals 'merits, administrative seniority and professional seniority at least ten years.

[SP11] Academic career on educational administration should be considered as well as administrative and professional seniority.

[VP19] Individuals' merits and academic career on educational administration should be considered as the main criteria to appoint a school principal. 
[VP15] Principals should be appointed among the vice principals who have at least four years administrative seniority. In-service training, professional seniority and work performance should be considered as well.

The frequency and percentages of sub-themes related to the main theme of training and experience are presented in Table 6.

Table 6

Sub-themes of Training and Experience $(\eta=40)$

\begin{tabular}{llcccc}
\hline \multirow{2}{*}{ Sub-theme } & Principals & Vice principals & \\
\cline { 2 - 5 } & $f$ & $f$ & Total & $\%$ \\
\hline Administrative seniority & 6 & 10 & 16 & 28.6 \\
Individuals' merits & 5 & 10 & 15 & 26.8 \\
& Academic career on educational administration & 7 & 5 & 12 & 21.4 \\
& Professional seniority & 4 & 8 & 12 & 21.4 \\
& In-service training & 1 & - & 1 & 1.8 \\
\hline Total & 23 & 33 & 56 & 100 \\
\hline
\end{tabular}

In Table 6, it is seen that training and experience is considered another important appointment criterion. The sub-themes are administrative seniority ( $\mathrm{f}=16,28.6 \%$ ), individuals' merits $(f=15,26.8 \%)$, academic career on educational administration $(f=$ $12,21.4 \%)$, professional seniority $(f=12,21.4 \%)$ and in-service training $(f=1,1.8 \%)$.

The views related to the main theme of scoring are as follows:

[SP5] Administrator selection exam score and administrative performance score should be considered as well as individuals'merits, administrative and professional seniority.

[SP7] Administrator selection exam score, interview score and administrative performance score should be considered.

[VP7] Principals should be appointed considering administrator selection exam score. Administrative performance criteria should be determined, and the appointments also should be carried out considering administrative performance points.

[VP18] Neither professional seniority nor academic career should solely be considered.

Table 7

Sub-themes of Scoring $(\eta=40)$

\begin{tabular}{llcccc}
\hline \multirow{2}{*}{ Sub-theme } & Principals & Vice principals & \\
\cline { 2 - 5 } & $f$ & $f$ & Total & $\%$ \\
\hline Administrator selection exam score & 8 & 9 & 17 & 44.7 \\
& Interview score & 5 & 4 & 9 & 23.7 \\
& Administrative performance score & 1 & 7 & 8 & 21.1 \\
& Assessment score given by school stakeholders & 2 & 1 & 3 & 7.9 \\
& Project score related to the school administration & - & 1 & 1 & 2.6 \\
\hline Total & & 16 & 22 & 38 & 100 \\
\hline
\end{tabular}


Assessment scores given by stakeholders, administrator selection exam point and interview point should be considered as well.

The frequency and percentages of sub-themes related to the main theme of scoring are presented in Table 7.

Table 7 shows that the principals and vice principals assert scoring as another important criterion. The sub-themes are the administrator selection exam score ( $\mathrm{f}=$ $17,44.7 \%)$, interview score $(f=9,23.7 \%)$, administrative performance score ( $f=$ $8,21.1 \%)$, assessment score given by school stakeholders $(\mathrm{f}=3,7.9 \%)$ and project score related to school administration $(f=1,2.6 \%)$.

\section{A New Model Proposal for the Turkish Educational System}

In Turkey, the training and appointment of school principals continues to be a major problem in the education system. In 1924, the famous American philosopher, psychologist and educational reformer John Dewey was invited to Turkey by the Ministry of Education, and he recommended that school administrators should be educated in educational institutions. According to Dewey (1939), the training course for school administrators and inspectors start in one of the teacher training schools and the successful teachers in educational practices should attend it. The Merkezi Hükümet Teşkilatı Araştırma Projesi (MEHTAP) report by TODAİE in 1963 predicted that candidate teachers should be trained for school management during university education and serve as school principals after graduation (TODAIE, 1966). In Turkey, until the 2000s, school principals were seen as bureaucratic managers appointed on the basis of seniority, career and individual merits from among the pool of effective vice principals or teachers (Aydın, 2010; Bursalıoğlu, 2005; Çelik, 2000; Şişman, 2010; Taymaz, 2003).

Different training and appointment models have been suggested in previous studies, such as the professionalisation of school administration (Akbaşlı \& Balıcç1, 2013), a preparation, selection and professional development model (Altın \& Vatanartiran, 2014), a new pre-service and in-service training model (Balyer \& Gündüz, 2012), mentoring (Ereş, 2009), a training programme (Işık, 2003) and a manager training academy (Okçu, 2011). In these models, suggestions have been partially provided regarding the determination of candidates with an examination, training or in-service training. However, an integrated model has not yet been developed.

\section{Principal Preparation Programme (Certificate Programme)}

In Turkey, in-service training programmes for principals have historically been an iteration of courses, including general management principles, school laws, administrative requirements and procedure, whereas little emphasis is given to student 
learning, effective teaching, professional development, curriculum and organisational change (Balyer, 2012). School principals trained and employed on the basis of this type of in-service training programme are far from being true administrators for today's schools. In this regard, quality certificate programmes should be organised by the Ministry of Education in cooperation with universities. In many countries, particularly in the USA, principal preparation programmes are conducted by the Ministry of Education, universities and different educational leadership institutes. These programmes have also been criticised for not being based on theory and practice (Chapman, 2005; Davis, Darling-Hammond, Meyerson, \& LaPointe, 2005). In this regard, quality certificate programmes should be organised by the Ministry of Education in cooperation with universities. Consequently, the certificate programmes should include student learning, effective teaching, instructional leadership, coaching, effective communication, human relations, school development, strategic planning, team management, crisis management, conflict management, problem solving, organisational change, curriculum development, professional development, budgeting, and so on. The candidates should be trained by professors in different universities and experts in educational administration. The courses should be based on theory and practice. Considering theory and practice-based training, the training period should not be less 240 hours (Darling-Hammond, LaPointe, Meyerson, Orr, \& Cohen, 2007; Ereş, 2009; Turnbull, Riley, \& MacFarlane, 2013). The envisaged features of the qualified school principal preparation programme are as follows (www.ncsl.org; nbctwawe.org):

(i) Targeted recruitment and selection: Identify candidates with leadership potential. Candidates wishing to become school principals primarily need to pass a written exam and interview.

(ii) Strong partnerships: Create an authentic partnership among districts and universities to ensure effective recruitment and selection, co-designing relevant coursework, field experiences and internships. Provide continuous on-the-job support for new principals.

(iii) Challenging, coherent curriculum: Set a curriculum that links theory and practice and integrates coursework focused on instructional leadership and the ability to change school culture and improve teacher effectiveness. The curriculum should be aligned with state and professional standards for school leaders. Faculty should be knowledgeable and competent.

(iv) Active instruction: Active instructional strategies that link theory and practice. Required instruction that emphasises problem-based learning, interactive learning field-based projects, professional reflection, strategic planning, budget exercises and effective data use. Such instruction engages university professors and practitioners who are knowledgeable in their subject fields. 
(v) Quality internships and school-based residency programmes: Offer well-designed and supervised internships or school-based residencies that provide real opportunities for aspiring principals to experience leadership.

(vi) Social and professional support: Provide proponent structures and formalised mentoring and advising by expert principals.

(vii) Candidate and programme assessment: Use assessments that are linked to standards and programme mission and objectives for programme and candidate improvement.

\section{The Selection of School Principals}

Considering the findings of this study and practices in different countries, it is said that school administrators can be appointed using an election model in Turkey. In Anglo-American countries such as Canada, the USA and Australia; Western Europe countries such as the Netherlands and Spain and Scandinavian countries such as Sweden, Norway, Denmark and Finland, school administrators are elected by a committee or delegation generally responsible for the management of the school (Şimşek, 2014; Taipale, 2012). On behalf of the enforcement of a democratic management system countrywide, particularly in schools, this model should also be considered essential. To avoid any controversy and to establish credibility, the election process should be conducted on several principles. The main principles should be considered as follows: (i) the school principal should be elected by school community members, (ii) teachers working at the school (including the school principal and vice principals) can be candidates, (iii) candidates have to provide the School Council's recognition for election qualification, (iv) candidates need at least $50 \%$ of the votes to serve as a principal, (v) the school principal should be elected for five years, (vi) vice principal(s) should be designated by the school principal, (vii) for a newly established school, a founding administrator should be appointed for five years from among experienced vice principals and (viii) the founding administrator should be appointed by the governor considering the district national education director's opinion.

Considering the criteria in previous studies conducted by Browne-Ferrigno and Muth (2010), Bush (2007), Davies, Ellison, and Bowring-Carr (2005), Goldring and Sims (2005), Hallinger and Heck (1998), James, Connolly, Dunning, and Elliot (2006), Lashway (2003), Leithwood, Seashore-Louis, Anderson, and Wahlstrom (2004) and Waters, Marzano, and McNulty (2003) as well as the findings and appointment criteria from this study, it can be suggested that the candidates should meet the following criteria: (i) have graduated from a university, (ii) hold a school management certificate, (iii) have served as a teacher for at least five years, (iv) have completed projects for school management, (v) have human relations and communication skills, (vi) have leadership characteristics (reason for preference) 
and (vii) have an MA or $\mathrm{PhD}$ in educational administration (reason for preference). The applications should be evaluated by the School Council. The School Council Members should be (i) the district director of national education (the president of the school council), (ii) the school principal, (iii) the vice principal in-charge of the school's personnel affairs (performs the secretarial tasks of the council), (iv) a teacher selected by the board of teachers by receiving at least one-third of the votes, (v) the president of the student council (only for high schools), (vi) the PTA president, (vii) a representative chosen by parents by receiving at least one-third of the votes and (viii) one of the school district councillors (the headmen in villages). School Council Members should have different duties, which include (i) providing an effective school-community collaboration, (ii) evaluating the applications and introducing candidates' projects to the school community, (iii) recognising the candidate who receives at least $50 \%$ of the vote as a school administrator, (iv) approving the school's annual programme in accordance with the teachers' board decision, (v) examining and evaluating projects, (vi) approving project funding and (vii) fulfilling other tasks concerning the functioning of the school.

School principals should be elected by the School Community Members. The School Community Members are (i) the teachers (including principal and vice principals), (ii) the parents, (iii) the students (only for high schools) and (iv) the school officials. School Community Members have different responsibilities and duties, which include (i) voting for candidates and (ii) terminating administrative positions in cases when general discontent emerges from the administrative practices of a school principal. At least $50 \%$ of the votes are necessary for this.

\section{Conclusion}

When views related to frequently changing regulations are considered, it is seen that school administrators find the regulations both positive and negative. The regulations have been found to be negative by participants, but the results show that they have also been seen as positive. The positive aspects of frequently changing regulations are the ineligible school principal's displacement, willing administrator's appointment, clarity of task period in the same school, encouraging success and definition of certain rules for appointment as a principal. Based on the abovementioned views, it can be said that frequently changing regulations have positive aspects. Furthermore, when qualified administrators are appointed instead of ineligible principals, they will presumably contribute to school improvement and student success rates. Considering the correlation between the students' success rates and school administrators' qualifications, the results are confirmed by previous studies conducted by Bolivar and Moreno (2006), Peterson (2002), Petzko, Clark, Valentine, and Hackmann (2002), Salisbury and McGregor (2005) and Shelton (2012). 
Notwithstanding, an important number of school administrators find the continually changing regulations to be negative. According to the findings, senior managers were said to have not acted impartially during the appointment process. The main indicators for this situation are violating impartiality, appointing individuals by considering political concerns and favouritism during interviews. Moreover, ignoring individuals' merits is seen to be another indicator of favouritism by school administrators. Furthermore, only one vice principal stated that there were no negative aspects of the frequently changing regulations. The previous studies conducted by Kaya (1997), Saydam (1994) and Tonbul and Sağıroğlu (2012) corroborate these findings. According to the findings, the frequently changing regulations cause major administrative problems such as the lack of motivation, adaptation problems in one's new place of employment, decrease in administrative autonomy, impossibility of longterm projects and decrease in productivity. Previous studies conducted by Altin and Vatanartıran (2014), Akçadağ (2014) and Aslanargun (2012) confirm these findings.

According to the school administrators' opinions, leadership skills are the most important criteria in school principal appointments. In previous studies conducted by Balcı and Çınkır (2003), Leithwood, Jantzi, and Steinbach (1999), Leithwood and Jantzi (2000), Leithwood, Louis, Anderson, and Wahlstrom (2004) and Leithwood, Day, Sammons, Harris, and Hopkins (2006), leadership characteristics are the most important criteria in school principal appointments. However, in the latest regulations dated October 2015, leadership skills are not predicted as the main criterion (Resmi Gazete, 2015). The findings show that for school administrator appointments, the other criteria are communication skills, human relations, fairness, innovativeness, predisposition to teamwork and personal improvement. School administrators also state that administrative seniority, individuals' merits, academic career on educational administration, professional seniority and in-service training should be considered. The latest regulations employ these criteria (Resmi Gazete, 2015). Considering these appointment criteria, it is realised that the results are consistent with the findings in previous studies conducted by Pont et al. (2008) and Taipale (2012). The other appointment criteria are the school administrator exam score, interview score, administrative performance score, assessment score given by school stakeholders and project score related to school management. The first two of these criteria are considered in the appointment of school principals according to the latest regulations dated October 2015. However, candidates are not yet required to have a leadership certificate. According to the school administrators' opinions, different criteria should be taken into consideration in school principal appointments. Similar results have been revealed in previous studies, such as "objective criteria on academic careers in educational administration” (Akbaşlı \& Balıkçı 2013), “interview score, leadership features, communication skills and individuals' merits" (Özmen \& Kömürlü, 2010), "administrator selection exam score and administrative performance score" 
(Cemaloğlu 2005), "leadership features and predisposition to teamwork" (Çelik 2003), "in-service training" (Ereş 2009), "human relations and fairness" (Gümüşeli 2001), "administrative performance score and innovativeness" (Huber 2005), "leadership features, job seniority and administrative seniority" (Korkmaz 2005) and "academic career in educational administration" (Okçu 2011).

Frequent changes in regulations cause administrative problems such as confusion in school management, lack of motivation, adaptation problems in new duty places, decrease in productivity and the impossibility of long-term projects. In addition, favouritism in the interviews is detrimental to equality of opportunity. Furthermore, appointments based on political concerns are evaluated as impairing labour peace. They also cause a decrease in administrative autonomy and ignore individuals' merits. In Turkey, to put an end to these debates, school leadership certificate programmes should be disseminated and school principals should be elected by the school community, as done in democratically advanced countries. If the frequently changing regulations ensure the dismissal of ineligible principals, it can be seen as useful. In addition, if willing, qualified administrators are appointed instead of aged principals who have no particular purpose in the profession, this should be seen as affirmative in favour of the Turkish Education System. Leadership characteristics, communication skills and human relation skills were considered by the school administrators as the main criteria for school principal appointments. Based on the findings, it can be said that school leadership training programmes are urgently required. The selection exam is seen as a major criterion for school administrator appointments. It should be taken into account to ensure credibility by decision-making bodies in the Turkish Education System. It is seen that in-service training is not taken into account in any way by the school administrators, but academic career in educational administration is considered as a significant criterion. Consequently, it can be suggested that certification and training programmes will play an important role in meeting this need.

This study suggests that an effective and sustainable policy should be established to employ qualified school administrators. For this purpose, certificate programmes should be arranged by various competent universities in cooperation with the Ministry of Education. School principals should be selected by the school community considering proficiencies as well as certificate qualification. To create an effective and sustainable election system, equality and fairness should be considered the main principles during the election process. School administrators should not be elected on the basis of political concerns. Further research can be conducted on the objective criteria related to the selection model. Different studies can be conducted on different groups, such as parents, senior managers and students. Quantitative studies can also be conducted on the school principal selection model. 


\section{References}

Akbaşl1, S., \& Balıkçı, A. (2013). Okul yöneticisi ve öğretmen görüşlerine göre okul yöneticiliğinin meslekleşmesinin değerlendirilmesi [Evaluation of professionalization of school administration according to the school administrator, teacher perceptions]. Mersin Üniversitesi Eğitim Fakültesi Dergisi, 9(2), 366-377.

Akçadağ, T. (2014). Okul yöneticilerinin bakış açılarıyla yöneticilerin yetiştirilme, atama ve yer değiştirmeleri; sorunlar ve çözümler [The school administrator's viewpoints about training, assignment and transportation; problems and solutions]. Mehmet Akif Ersoy Üniversitesi Ĕgitim Fakültesi Dergisi, 29, 135-150.

Altın, F., \& Vatanartıran, S. (2014). Türkiye'de okul yöneticisi yetiştirme, atama ve sürekli geliştirme model önerisi [A model proposal for the preparation, selection, and professional development of school principals in Turkey]. Ahi Evran Üniversitesi Kırşehir Eğitim Fakültesi Dergisi,15(2), 17-35.

Aslanargun, E. (2012). Okul müdürlerinin atanmaları sürecinde idari yargı kararları ve öne çıkan değerler [Administrative judicial decisions on the process of principals' appointment and emerging values]. Kuram ve Uygulamada Eğitim Yönetimi Dergisi, 18(3), 347-376.

Aydın, M. (2010). Eğitim yönetimi [Educational management]. Ankara, Turkey: Hatipoğlu Basım Yayın.

Balcı, A., \& Çınkır, Ş. (2003). Türkiye'de eğitim yöneticilerinin yetiştirilmesi. In C. Elma \& Ş. Çınkır (Eds.), 21. yüzyıl eğitim yöneticilerinin yetiştirilmesi sempozyumu (pp. 211-236). Ankara, Turkey: Ankara Üniversitesi Eğitim Bilimleri Fakültesi Yayınları.

Balyer, A. (2012). Çağdaş okul müdürlerinin değişen rolleri [Changing roles of contemporary school principals]. Ahi Evran Üniversitesi Kırşehir Eğitim Fakültesi Dergisi, 13(2), 75-93.

Balyer, A., \& Gündüz, Y. (2011). Değişik ülkelerde okul müdürlerinin yetiştirilmesi: Türk eğitim sistemi için bir model önerisi [Training school principals in different countries: A new model proposal for the Turkish Educational System]. Kuramsal Eğitimbilim, 4(2), 182-197.

Bolivar, A., \& Moreno, J. M. (2006). Between transaction and transformation: The role of school principals as education leaders in Spain. Journal of Educational Change, 7(1-2), 19-31.

Browne-Ferrigno, T., \& Muth, R. (2010). Recruitment and retention of quality principals: Essential for successful schools. Education Leadership and Administration, 20, 19-45.

Bursalığlu, Z. (2005). Eğitim yönetiminde teori ve uygulama [Theory and practice in educational management]. Ankara, Turkey: Pegem A Yayıncılık.

Bush, T. (2007). Educational leadership and management: Theory, policy, and practice. South African Journal of Education, 27(3), 391-406. Retrieved from www.ajol.info/index.php/ saje/article/.../4321

Çelenk, S. (2003). 21. yüzyıl eğitim yöneticilerinin yetiştirilmesi sempozyumu. In C. Elma \& Ş. Çınkır (Eds.), Geleceğin eğitim yöneticilerinin yetiştirilmesinde bir model önerisi, (pp. 65-81). Ankara, Turkey: Ankara Üniversitesi Eğitim Fakültesi Yayınları.

Çelik, V. (2000). Okul kültürü ve yönetimi [School culture and management]. Ankara, Turkey: Pegem A Yayıncılık.

Çelik, V. (2003). 21. yüzyıl eğitim yöneticilerinin yetiştirilmesi sempozyumu. In C. Elma \& Ş. Çınkır (Eds.), Ĕ̈itim yöneticisi yetişstirme politikalarına yön veren eğilimler, (pp. 3-12). Ankara, Turkey: Ankara Üniversitesi Eğitim Fakültesi Yayınları. 
Cemaloğlu. N. (2005). Türkiye'de okul yöneticisi yetiştirme ve istihdamı; var olan durum, gelecekteki olası gelişmeler ve sorunlar [The training of school principals and their employment in Turkey: Current situation, possible developments in the future and problems]. Gazi Üniversitesi, Gazi Eğitim Fakültesi Dergisi, 25(2), 249-274.

Chapman, J. D. (2005). Recruitment, retention, and development of school principals. Paris, France: The International Institute for Educational Planning. Retrieved from http://unesdoc. unesco.org/images/0014/001409/140987e.pdf

Creswell, J. W. (2015). Beş yaklaşıma göre nitel araştırma ve araştırma deseni [Qualitative inquiry \& research design choosing among five approaches] (Trans. Eds. M. Bütün \& S. B. Demir). Ankara, Turkey: Siyasal Kitabevi.

Darling-Hammond, L., LaPointe, M., Meyerson, D., Orr. M. T., \& Cohen, C. (2007). Preparing school leaders for a changing world: Lessons from exemplary leadership development programs. Stanford, CA: Stanford University, Educational Leadership Institute. Retrieved from http://www.wallacefoundation.org/knowledge-center/school-leadership/key-research/Documents/Preparing-School-Leaders.pdf

Davies, B., Ellison, L., \& Bowring-Carr, C. (2005). School leadership in the $21^{\text {st }}$ century. London, UK: RoutledgeFalmer.

Davis, S., Darling-Hammond, L., LaPointe, M., \& Meyerson, D. (2005). Review of research. School leadership study. Developing successful principals. Palo Alto: Stanford Educational Leadership Institute. Retrieved from http:/www.wallacefoundation.org/knowledge-center/ school-leadership/principal-training/Pages/Developing Successful-Principals.aspx

Degenhardt, L. M. (2006). Reinventing a school for the $21^{\text {st }}$ century: A case study of change in a Mary Ward school (Doctoral dissertation, Australian Catholic University, Sydney). Retrieved from http://www-library.acu.edu.au/.../adt-acuvp99.29082006/

Demirtaş, H., \& Özer, N. (2014). Okul müdürlerinin bakış açısıyla okul müdürlügü [School principalship from the perspectives of school principals]. Kastamonu Eğitim Dergisi, 22(1), 1-24.

Denzin, N. K., \& Lincoln, Y. S. (2005). The sage handbook of qualitative research. California, CA: Sage.

Dewey, J. (1939). Türkiye maarifi hakkında rapor [Report and recommendation upon Turkish education]. İstanbul: Devlet Basımevi.

Ereş, F. (2009). Okul yöneticilerinin yetiştirilmesinde mentörlük [Mentoring in training of school managers]. Kafkas Üniversitesi Sosyal Bilimler Enstitüsü Dergisi, 2(3), 157-165.

Goldring, E., \& Sims, P. (2005). Modeling creative and courageous school leadership through district-community-university partnerships. Educational Policy, 19(1), 223-249. http:// dx.doi.org/10.1177/0895904804270777

Gümüşeli, A. İ. (2001). Çağdaş okul müdürünün liderlik alanları [Leadership fields of the contemporary school manager]. Kuram ve Uygulamada Eğitim Yönetimi, 7(28), 531-548.

Hallinger, P., \& Heck, R. H. (1998). Exploring the principal's contribution to school effectiveness: 1980-1995. School Effectiveness and School Improvement, 9, 157-191. http://dx.doi.org/10.1080/0924345980090203

Helvacı, M. A., \& Aydoğan, İ. (2011). Etkili okul ve etkili okul müdürüne ilişkin öğretmen görüşleri [A study on the perceptions of teachers on the qualities of effective school and school principal]. Uşak Üniversitesi Sosyal Bilimler Dergisi, 4(2), 41-60. 
Hesapçıoğlu, M. (1998). Türkiye'de eğitim yönetimi [Educational management in Turkey]. In M. Hesapçıŏlu \& H. Taymaz (Eds.), Postmodern çağda eğitim yönetimi ve eğitim örgütü (pp. 97-103). Ankara, Turkey: Kültür Koleji Eğitim Vakfi Yayınları.

Huber, S. G. (2005). Preparing school leaders for the $21^{\text {st }}$ century. London, UK: Taylor \& Francis Group.

Işı1k, H. (2003). Okul müdürlerinin yetiştirilmelerinde yeni bir model önerisi [A new model for training the school administrators]. Hacettepe Üniversitesi Eğitim Fakültesi Dergisi, 24, 206-211.

James, C. R., Connolly, M., Dunning, G., \& Elliott, T. (2006). How very effective primary schools work. London, UK: Sage.

Karadağ, E. (2011). Okul müdürlerinin niteliklerine ilişkin olarak ögretmenlerin oluşturduklart bilişsel kurgular: Fenomonolojik bir çözümleme [Teachers' cognitive fictions of elementary school principals' qualifications: A phenomenological analysis]. Eğitim ve Bilim, 36(159), 25-40.

Karip, E., \& Köksal, K. (1999). Okul müdürlerinin yetiştirilmesi [Training of the school principals]. Kuram ve Uygulamada Eğitim Yönetimi, 5(18), 193-204.

Kaya, Y. K. (1997). Eğitim yönetimi: Kuram ve Türkiye’deki uygulama [Educational management: Theory and Practice in Turkey]. Ankara, Turkey: Bilim Yayınları.

Korkmaz, M. (2005). Okul yöneticilerinin yetiştirilmesi: Sorunlar- çözümler ve öneriler [Training school managers: Problems, solutions and suggestions]. Gazi Eğitim Fakültesi Dergisi, 25(3), 237-252.

Lashway, L. (2003). Role of the school leader: Trends and issues. Journal of Curriculum and Supervision, 18(3), 240-258.

Leithwood, K., \& Jantzi, D. (2000). Leadership for change and school reform. In K. Riley \& K. S. Louis (Eds.), The effects of different sources of leadership on student engagement in school (pp. 50-66). New York, NY: Routledge.

Leithwood, K., Day, C., Sammons, P., Harris, A., \& Hopkins, D. (2006). Seven strong claims about successful school leadership. Nottingham: National College for School Leadership. Retrieved from http://www.leadershipinnovationsteam.com/files/seven-strong-claims.pdf

Leithwood, K., Jantzi, D., \& Steinbach, R. (1999). Changing leadership for changing times. Buckingham, UK: Open University Press.

Leithwood, K., Seashore-Louis, K., Anderson, S., \& Wahlstrom, K. (2004). How leadership influences student learning. New York, NY: The Wallace Foundation. Retrieved from http://www.wallacefoundation.org/knowledge-center/school-leadership/key-research/ Pages/How-Leadership-Influences-Student-Learning.aspx

Lunenburg, F. C. (2010). The principal and the school: What do principals do? National Forum of Educational Administration and Supervision Journal, 27(4), 1-13. Retrieved from http://www.nationalforum.com/

Marshall, C., \& Rossman, B. G. (2006). Designing qualitative research. California, CA: Sage.

Miles, M. B., \& Huberman, M. A. (1994). An expanded sourcebook qualitative data analysis. London, UK: Sage.

Okçu, V. (2011).Türkiye'de okul yöneticilerinin yetiştirilmesi ve atanmasına ilişkin mevcut durum, beklentiler ve öneriler [Current situations, expectation and suggestions concerning schol manager traininig and assignment in Turkey]. Elektronik Sosyal Bilimler Dergisi, 10(37), 244-266. 
Özmen, F., \& Kömürlü, F. (2010). Eğitim örgütlerine yönetici seçme ve atamada yaşanan sorunlar ve yönetici görüşleri temelinde çözüm önerileri [The problems occur in selection and appointment of administrator in education organizations and solution proposals on the basis of managers' views]. Sosyal ve Beşeri Bilimler Dergisi, 2(1), 25-33.

Peterson, K. (2002). The professional development of principals: Innovations and opportunities. Educational Administration Quarterly, 38(2), 213-232. http://dx.doi. org/10.1177/0013161X02382006

Petzko, V. N., Clark, D. C., Valentine, J. W., \& Hackmann, D. G. (2002). Leaders and leadership in middle level schools. NASSP Bulletin, 86(631), 3-15. http://dx.doi.org/10.1.1.471.4367

Pont, B., Nusche, D., \& Moorman, H. (Eds.). (2008). Improving school leadership: Volume 1. policy and practice. Paris, France: OECD Publications. Retrieved from www.oecd.org/ edu/school/44374889.pdf

Portin, B. S., Alejano, C. R., Knapp, M. S., \& Marzolf, E. (2006). Redefining roles, responsibilities, and authority of school leaders. Washington, DC: The Wallace Foundation.

Resmi Gazete. (1965). Date: July, 1965. Issue: 12056.

Resmi Gazete. (1998). Date: September, 1998. Issue: 23472.

Resmi Gazete. (1999). Date: April, 1999. Issue: 23681.

Resmi Gazete. (2014). Date: June, 2014. Issue: 29026.

Resmi Gazete. (2015). Date: July, 2015. Issue: 29410.

Resmi Gazete. (2015). Date: October, 2015. Issue: 29494.

Salazar, P. (2007). Changing role of the middle level and high school leader: Learning from the past-preparing for the future. In J. Phillip (Ed.), Changing expectations of the position, (pp. 5-17). Virginia: National Association of Secondary School Principals. Retrieved from http://docplayer.net/3948228-Changing-role-of-the-middle-level-and-high-school-leaderlearning-from-the-past-preparing-for-the-future.html

Salisbury, C., \& McGregor, G. (2005). Principals of inclusive schools. Retrieved from www. urbanschools.org/

Saydam, R. (1994). Öğretmenler okullara sandık istiyor [Teachers want the polls to schools]. Öğretmen Dünyası Dergisi, 15(170), 7-12.

Shelton, S. (2012). Preparing a pipeline of effective principals: A legislative approach. Washington, DC: National Conference of State Legislatures. Retrieved from http://www. wallacefoundation.org/knowledge-center/school-leadership/state-policy/Documents/ Preparing-a-Pipeline-of-Effective-Principals-A-Legislative-Approach.pdf

Şimşek, H. (2014). Mehter yürüyüşü: Okul müdürlerinin atanması [Mehter march: The appointment of school principals]. Retrieved from www.turkiyekamu.com/.../

Singh, K. (2007). Quantitative social research methods. California, CA: Sage.

Şişman, M. (2010). Türk eğitim sistemi ve okul yönetimi [Turkish education system and school management]. Ankara, Turkey: Pegem A Yayıncılık.

Şişman, M., \& Turan, S. (2004). Eğitim ve okul yöneticiliği. In Y. Özden (Ed.), Eğitim ve okul yönetimi (pp. 99-146). Ankara, Turkey: Pegem A Yayıncılık.

Taipale, A. (2012). International survey on educational leadership. Helsinki: Finnish National Board of Education. Retrieved from www.oph.fi/.../143319_International_survey 
Taş,A., \& Önder, E. (2012). 2004 yılı ve sonrasında yayımlanan eğitim kurumları yöneticilerinin atama ve yer değiştirmelerine ilişkin yönetmeliklerin karşılaştırılması [Comparison the regulations on the assignment and relocation of administrators of educational institutions functioning in 2004 and the years later]. Süleyman Demirel Üniversitesi Sosyal Bilimler Enstitüsü Dergisi, 2(12), 171-185.

Taymaz, H. (2003). Okul yönetimi [School management]. Ankara, Turkey: Pegem A Yayıncılık.

Tonbul, Y., \& Sağıroğlu, S. (2012). Okul müdürlerinin zorunlu yer değiştirme uygulamasına ilişkin bir araştırma [A research regarding to obligatory displacement about school administrators]. Kuram ve Uygulamada Eğitim Yönetimi, 18(2), 313-339.

Turan, S., Yıldırım, N., \& Aydoğdu, E. (2012).Okul müdürlerinin kendi görevlerine ilişkin bakış açıları [Perspectives of school principals on their own task]. Pegem Eğitim ve Öğretim Dergisi, 2(3), 63-76.

Türkiye ve Ortadoğu Amme İdaresi Enstitüsü. (1966). Merkezi hükümet teşkilatı araştırma projesi yönetim kurulu raporu [Organization and functions of the central government of Turkey; report of the Managing Board of the Central Government Organization Research Project]. Ankara, Turkey: Author.

Turnbull, B. J., Riley, D. L., \& MacFarlane J. R. (2013). Cultivating talent through a principal pipeline. New York, NY: The Wallace Foundation.

Waters, J. T., Marzano, R. J., \& McNulty, B. A. (2003). Balanced leadership: What 30 years of research tells us about the effect of leadership on student achievement. Aurora, CO: Midcontinent Research for Education and Learning. Retrieved from http://www.ctc.ca.gov/ educator-prep/ASC/5031RR_BalancedLeadership.pdf

Yıldırım, A., \& Şimşek, H. (2013). Sosyal bilimlerde nitel araştırma yöntemleri [Qualitative research methods in social sciences]. Ankara, Turkey: Seçkin Yayınevi. 